\title{
Improving of Identifying Poetry Text Building Elements Ability Through a Contextual Approach at Class VIII SMP Negeri 42 Oku
}

\author{
Yossy Aprianti $^{1 *}$, Ratu Wardarita ${ }^{2}$, Dessy Wardiah $^{2}$ \\ ${ }^{1} S M K$ Negeri 42 OKU \\ ${ }^{2}$ Universitas PGRI Palembang \\ *Corresponding author. E-mail: tomasbaturaja@gmail.com
}

\begin{abstract}
This article aims to improve the ability to identify the building blocks of poetry text through a contextual approach to the eighth grade students of SMP Negeri 42 OKU. The researcher used Classroom Action Research (PTK). Based on the results of the action research, it can be concluded that there was an increase in the ability to identify the building blocks of poetry text through a contextual approach in grade VIII students at SMP Negeri 42 OKU. There was an increasing the ability to identify the building blocks of poetry text through a contextual approach to the eighth grade students of SMP Negeri 42 OKU in each cycle. It was known that in the action cycle 1 the value obtained is 2220 with an average of 69.38 . The 17 students who complete with an average percentage of completeness of $53.13 \%$. In cycle 2 there was an increase with an average of 70.63 . Students who completed were 23 students with an average percentage of completeness of $71.88 \%$. Then in the action cycle 3 has increased again with an average of 80.00 . Students who completed were 31 students with an average percentage of completeness of $96.88 \%$.
\end{abstract}

Keywords: Elements, Development, Poetry Text, Contextual Approach

\section{INTRODUCTION}

The learning literature aims to increase the ability to appreciate literature, which means that after studying literature, students are expected to be able to recognize, understand, appreciate, and appreciate literary works. As a mirror that shows a symbol of progress in the life of a nation.

In poetry learning activities, students are directed to understand theories related to the building blocks of poetry, such as themes, messages, poet feelings, figure of speech, rhythm, word connotations, words with symbols, and inspiration [1][2]. Learning literature, especially poetry, cannot be ignored, but it needs to be instilled in students, so that students get a broad knowledge of understanding and its application [3], so that students have a positive attitude towards literature (poetry).

Poetry is a variety of literature whose language is bound by rhythm, dimension, rhyme, and arrangement of lines and stanzas [4]. In addition, poetry is also defined as a poem or composition in a language whose form is carefully chosen and arranged so as to sharpen people's awareness of experiences and generate special responses through structuring sounds, rhythms, and special meanings. Usually poetry is made to express the thoughts and feelings of the author by giving priority to the beauty of words.

Poetry is a written work of art that contains expressions of feelings by using language that is semantically meaningful and contains rhythm, rhyme, and rhythm in the arrangement of lines and stanzas [5]. Understanding the true meaning in a poem, it is necessary to understand what are the building blocks of poetry. The building blocks of poetry are divided into intrinsic and extrinsic elements.

According to Wardoyo, intrinsic elements are elements contained in the body of literary works. Every literary work, whether poetry, prose, or drama, has a different intrinsic element [6]. Furthermore, He argues that extrinsic elements are the building blocks of poetry that are outside the poetry manuscripts which influence the existence of literary works as works of art.

Aminuddin asserted that poetry is a literary poet who expresses feelings and estimates with words that are very short and simple, but still beautiful when it is read. [7] In addition, writing activities that a person 
has does not just come automatically, but it all starts with continuous practice, full of diligence and pay attention on grammatical language including what kinds of tenses that should be used for their writing [16][17]. A similar expression was also put forward by Aminudddin, arguing that writing is a part of the same type of skill as other skills, to acquire it through learning and practicing, getting used to, that is the key.

Dzaki explains that poetry is a paraphrase of experience which is interpretive (interpreting) in rhythmic/meaningful language [9]. Furthermore, according to Kosasih poetry is a form of literary work that uses beautiful words contained in the literary work [10]. Furthermore, Waluyo argues that poetry is a literary work with language that is condensed, shortened and given a rhythm with a unified sound and a selection of (imaginative) study words [11] [12].

Regarding poetry learning in relation to the 2013 Revised Curriculum, specifically the curriculum for learning Indonesian is a text-based curriculum. This means that students who are in the SMP/MTs, SMA/ MA, SMK education levels must be able to understand and apply various texts specified in the curriculum. One of the texts that must be mastered by grade VIII junior high school students is the ability to identify the building blocks of poetry text.

Based on the results of the researcher's preliminary data, for two semesters the students of class VIII -A SMP Negeri 42 OKU in teaching the material identified the elements of the building blocks of poetry text, with an average student score of 62 . This means that the minimum critical completeness (KKM) of 65 still uses the lecture and assignment method, so that in the learning process the students' ability to identify the building blocks of poetry texts is deemed necessary to be improved through a contextual approach.

To harmonize the Indonesian language learning process related to identifying the building blocks of poetry text, it is necessary to have a learning approach so that the learning process can run effectively and efficiently. One approach that is considered good in learning to identify the building blocks of poetry text is to use a contextual approach.

According to [7],there are several advantages in learning through a contextual approach , namely: (1) learning is more meaningful, meaning that students carry out activities related to the existing material themselves so that students can understand them by themselves; (2) learning is more productive and able to foster concept reinforcement in students because learning through contextual demands students; (3) find themselves not memorized: (4) m enumbuhkan courage students to express opinions about the material learned; (5) m enumbuhkan curiosity about the material learned to ask the teacher: (6) $\mathrm{m}$ enumbuhkan ability to cooperate with other friends to solve the existing problems; and (7) students can make their own conclusions from learning activities.

The contextual approach is a holistic learning process that aims to teach students to understand teaching materials in a meaningful way that is associated with real life contexts, whether related to personal, religious, social, economic, or cultural environments. Thus, students acquire knowledge and skills [8], A contextual approach is teaching that allows students to strengthen, expand, and apply their knowledge and academic skills in various school settings and outside of school to solve all problems that exist in the real world [9],

In line with the explanation above, argues that contextual is a learning system that is suitable for brain performance, to compose patterns that embody meaning, by connecting academic content with the context of students' daily life. This is important so that the information received is not only stored in short-term memory, which is easy to forget, but can be stored in long-term memory so that it will be appreciated and applied in work tasks. A contextual approach is a learning concept that helps teachers link the material they teach with students' real-world situations and encourages students to make connections between their knowledge and its application in their lives as members of society.

Based on the description above, the student's ability to identify elements of the building blocks of poetry texts that have not reached the KKM, so it needs to be improved through a contextual approach.

\section{METHODS}

According [10], the procedure each cycle consists of four phases: planning, (2) the action, (3) observation, (4), reflection. The research operational steps include the preparation stage, the planning stage, the action stage, the observation stage, and the reflection stage. This research was conducted in several cycles with indicators of success guidelines and if not met, corrective steps will be taken in the next cycle.

\section{RESULTS AND DISCUSSION}

Based on the results of action research, it is known that there is an increase in the ability to identify the building blocks of poetry text through a contextual approach to the eighth grade students of SMP Negeri 42 OKU. The increase in the ability to identify the building blocks of poetry text through a contextual approach in class VIII students at SMP Negeri 42 OKU in each cycle, it is known that in the action cycle 1 the value obtained is 2220 with an average of 69.38 . There were 17 students who completed with an average percentage of completeness of $53.13 \%$. In cycle 2 there was an increase where the achievement of the results obtained a 
value of 2260 with an average of 70.63. Students who completed were 23 students with an average percentage of completeness of $71.88 \%$. Then in the action cycle 3 has increased again where the results obtained are 2560 with an average of 80.00 . Students who completed were 31 students with an average percentage of completeness of $96.88 \%$.

Some of the advantages of using a contextual approach in learning to improve the ability to identify the building blocks of poetry text in grade VIII students at SMP Negeri 42 OKU, including (1) building students' understanding of new practices in the learning process, (2) students can use skills critical thinking, (3) in teacher learning activities only guide, and open students' insights into thinking, (4) students can exchange experiences from the learning results that have been conveyed, (5) students can share ideas in solving existing problems.

As stated by Trianto there are several advantages in learning through a contextual approach, [13] namely: (1) learning is more meaningful, meaning that students carry out activities related to existing material so that students can understand them by themselves; (2) learning is more productive and able to foster concept reinforcement in students because learning through contextual demands students; (3) finding themselves not memorizing: (4) fostering the courage of students to express opinions about the material being studied; (5) fostering curiosity about the material being studied by asking the teacher: (6) fostering the ability to cooperate with other friends to solve existing problems; and (7) students can make their own conclusions from learning activities.

The contextual approach is a holistic learning process that aims to teach students to understand teaching materials in a meaningful way that is associated with real life contexts, whether related to personal, religious, social, economic, or cultural environments. Thus, students acquire knowledge and skills. A contextual approach is teaching that allows students to strengthen, expand, and apply their knowledge and academic skills in various school settings and outside of school to solve all problems that exist in the real world.

In line with the explanation above, argues that contextual is a learning system that is suitable for brain performance, to compose patterns that embody meaning, by connecting academic content with the context of students' daily life. This is important so that the information received is not only stored in short-term memory, which is easy to forget, but can be stored in long-term memory so that it will be appreciated and applied in work tasks. A contextual approach is a learning concept that helps teachers link the material they teach with students' real-world situations and encourages students to make connections between their knowledge and its application in their lives as members of society.

In poetry learning activities, students are directed to understand theories related to the building blocks of poetry, such as themes, messages, poet feelings, figure of speech, rhythm, word connotations, words with symbols, and pengimajian. Learning literature, especially poetry, cannot be ignored, but it needs to be instilled in students, so that students get a broad knowledge of understanding and its application, so that students have a positive attitude towards literature (poetry).

Poetry is a variety of literature whose language is bound by rhythm, dimension, rhyme, and arrangement of lines and stanzas. In addition, poetry is also defined as a poem or composition in a language whose form is carefully chosen and arranged so as to sharpen people's awareness of experiences and generate special responses through structuring sounds, rhythms, and special meanings. Usually poetry is made to express the thoughts and feelings of the author by giving priority to the beauty of words.

Poetry is a written work of art that contains expressions of feelings by using language that is semantically meaningful and contains rhythm, rhyme, and rhythm in the arrangement of lines and stanzas. Understanding the true meaning in a poem, it is necessary to understand what are the building blocks of poetry. The building blocks of poetry are divided into intrinsic and extrinsic elements [14] [15].

Poetry is a poet's literary work that expresses his feelings and estimates in very concise and simple words [2], but is still beautiful when read. In addition, writing that someone has does not just come automatically, but it all starts with continuous practice and full of diligence. A similar expression was also put forward arguing that writing is a part of the same type of skill as other skills, to acquire it through learning and practicing, getting used to, that is the key.

On the other hnd, poetry is a paraphrase of experience which is interpretive in rhythmic/meaningful language. Furthermore, according to [5], poetry is a form of literary work that uses beautiful words contained in the literary work. Furthermore, poetry is a literary work with language that is condensed, shortened and given a rhythm with a unified sound and a selection of (imaginative) study words. [6]

In connection with wheezing dentifikasikan elements of builders text of poetry, several studies relevant to help strengthen this research, including research conducted by observed, "The ability to identify Elements Builders Poetry Read At Grade VIII Odd Semester SMP Negeri 1 Way Tuba 2018/2019 Academic Year. " The results of this study explain that the ability to identify the building blocks of poetry text that is read in class VIII students of the odd semester of 
SMP Negeri 1 Waytuba in the 2018/2019 academic year can be said to be sufficient because the average score reaches 64 . In each aspect, it shows that the ability The students identified 57 theme elements achieving sufficient ability, on the feeling aspect achieving an average score of 63 in the sufficient category, and in the tone/atmosphere aspect achieving an average score of 55 in the poor category, and in the mandate aspect achieving an average score of 66 in the category enough. In this study, the researcher believes that there are similarities and differences with current research, namely both researching the building blocks of poetry, while the difference is that conducted a study with the title, "The Ability to Identify Poetry Building Elements Read in Classroom Students. VIII Odd Semester SMP Negeri 1 Way Tuba Academic Year 2018/2019, "further research is now examining," Increasing the Ability to Identify Elements of Building Poetry Texts Through a Contextual Approach to Class VIII Students at SMP Negeri 42 OKU. "

Rosalinda's research (2020) examines, "The Ability to Identify Elements of Building Poetry Texts for Class VIII Students of SMP Negeri Satap 10 Konawe Selatan." The results of this study concluded that out of 45 students who were research respondents, individually there were 21 students $(46.67 \%)$ who were in the capable category and 24 students $(53.33 \%)$ were categorized as unable to identify the building blocks of the text. poetry. Classically, the ability to identify the building blocks of poetry text for eighth grade students of SMP Negeri Satap 10 Konawe Selatan is in the underprivileged category. It is said that because the ability of individual students to achieve a minimum ability of $70 \%$ is only $46.67 \%$ not yet achieving the classical completeness criteria, namely $85 \%$. Judging from the level of students' ability, of the eight components which are aspects of the assessment, namely the aspects of the theme, mandate, figure of speech, rhythm, word connotation, symbolic words, and classically incomplete assessment because the percentage does not reach the classification criteria of $85 \%$ In this study, the researcher believes that there are similarities and differences with current research, namely both researching students' ability to identify elements of poetry text, while the difference is that Rosalinda (2020) researched, "The Ability to Identify Elements of Poetry Text Builder for Class VIII Students. SMP Negeri 10 Konawe Selatan Satap. " Furthermore, the present research examines, "Increasing the Ability to Identify Elements of Building Poetry Texts Through a Contextual Approach to Class VIII Students at SMP Negeri 42 OKU."

Massi's research (2014), with the title: "Analysis of Elements of Inner Structure of Several Poems in Poetry Anthology" Jakarta-Berlin ". The results of this study conclude that it raises the condition of the city of Jakarta which is not good for public health because it stores the seeds of malaria and of course this is a bad thing for human life in the city. In this study, the researcher believes that there are similarities and differences with current research, namely both researching poetry studies, while the difference with current research is, "Increasing the Ability to Identify Elements of Building Poetry Texts through a Contextual Approach to Class VIII Students at SMP Negeri 42 OKU."

Poetry is a written work of art that contains expressions of feelings using language that is semantically meaningful and contains rhythm, rhyme, and rhythm in the arrangement of lines and stanzas. Understanding the true meaning in a poem, it is necessary to understand what are the building blocks of poetry. The building blocks of poetry are divided into intrinsic and extrinsic elements.

In poetry learning activities, students are directed to understand theories related to the building blocks of poetry, such as themes, messages, poet feelings, figure of speech, rhythm, word connotations, words with symbols, and pengimajian. Learning literature, especially poetry, cannot be ignored, but it needs to be instilled in students, so that students get a broad knowledge of understanding and its application, so that students have a positive attitude towards literature (poetry).

Some of the advantages of using a contextual approach in learning to improve the ability to identify the building blocks of poetry text in grade VIII students at SMP Negeri 42 OKU, including (1) building students' understanding of new practices in the learning process, (2) students can use skills critical thinking, (3) in teacher learning activities only guide, and open students' insights into thinking, (4) students can exchange experiences from the learning results that have been conveyed, (5) students can share ideas in solving existing problems.

The contextual approach is a holistic learning process that aims to teach students to understand teaching materials in a meaningful way that is associated with real life contexts, whether related to personal, religious, social, economic, or cultural environments. Thus, students acquire knowledge and skills. A contextual approach is teaching that allows students to strengthen, expand, and apply their knowledge and academic skills in various school settings and outside of school to solve all problems that exist in the real world.

\section{CONCLUSION}

Based on the results of the action research, it can be concluded that there is an increase in the ability to identify the building blocks of poetry text through a contextual approach in grade VIII students at SMP 
Negeri 42 OKU. The increase in the ability to identify the building blocks of poetry text through a contextual approach in class VIII students at SMP Negeri 42 OKU in each cycle, it is known that in the action cycle 1 the value obtained is 2220 with an average of 69.38. There were 17 students who completed with an average percentage of completeness of $53.13 \%$. In cycle 2 there was an increase where the achievement of the results obtained a value of 2260 with an average of 70.63. Students who completed were 23 students with an average percentage of completeness of $71.88 \%$. Then in the action cycle 3 has increased again where the results obtained are 2560 with an average of 80.00 . Students who completed were 31 students with an average percentage of completeness of $96.88 \%$.

Based on the research results, the researcher provides the following suggestions. For schools, the school should be able to complete the learning infrastructure for teachers and students, such as more than one handbook, so that the learning process provided by the teacher can be even better. For teachers, it should be used as a reference in using a contextual approach to learning that refers to active, innovative, creative, effective and fun learning. For students, they should study seriously and pay attention to everything that is said by the teacher so that learning outcomes are even better.

\section{REFERENCES}

[1] Setiawan, A. Y. (2015). The symbols of human morals used by William Wordsworth in his selected poems (Doctoral dissertation, Universitas Islam Negeri Maulana Malik Ibrahim).

[2] Faulkner, S. L. (2016). Poetry as method: Reporting research through verse. Routledge.

[3] Prastiyono, Y. A., Fahmilda, Y., (2020). Pronoun, Personal Titles, and Variety of Java-Indonesian Language In "Yowis Ben The Series" Film: Contrastive Study. Anglophile Journal, 1(2).
[4] Huot, S. (2019). From song to book: the poetics of writing in old French lyric and lyrical narrative poetry. Cornell University Press.

[5] Belfi, A. M., Vessel, E. A., \& Starr, G. G. (2018). Individual ratings of vividness predict aesthetic appeal in poetry. Psychology of Aesthetics, Creativity, and the Arts, 12(3), 341.

[6] Wardoyo, M. S. (2013). Teknik Menulis Puisi. Yogyakarta: Graha Ilmu.

[7] Aminuddin. (2012). Pengantar Apresiasi Karya Sastra. Jakarta: Sinar Baru Algensindo.

[8] Hikmat, dkk. 2017. Kajian Puisi. Yogyakarta: Araska.

[9] Dzaki, M. (2012). Model-Model Pembelajaran. Jakarta: Rineka Cipta.

[10] Kosasih. (2013). Kajian Sastra. Jakarta: Rajawali Pers.

[11] Waluyo. J. H. (2005). Teori dan Apresiasi Sastra. Jakarta: Rajawali Pers.

[12] Trianto. 2014. Model-Model Pembelajaran. Jakarta: Rineka Cipta.

[13] Djojosuroto. (2016). Unsur Pembangun Puisi. Jakarta: Rineka Cipta.

[14] Rusman. (2014). Model-Model Pembelajaran ( Mengembangkan Profesionalisme Guru). Jakarta: Raja Grafindo Persda.

[15] Asrori, M. (2012). Prosedur Penelitian Tindakan Kelas. Jakarta: Rineka Cipta.

[16] Sari, Y. A. (2018). Applaying tell and show strategy on writtent text of young learners. Pedagogy: Journal of English Language Teaching, 6(1), 23-36.

[17] Haikal, H. (2018). Interactive metadiscourse and interactional metadiscourse categories of students'international program school based on gender. IJEE (Indonesian Journal of English Education), 5(1), 81-91. 